\title{
HUBUNGAN KEKURANGAN VITAMIN A DENGAN ANEMIA PADA ANAK USIA SEKOLAH
}

\author{
Idrus Jus'at', Sandjaja², Sudikno ${ }^{3}$, Fitrah Ernawati² \\ 1Program Studi IImu Gizi, Fakultas IImu-IImu Kesehatan, Universitas Esa Unggul, Jakarta \\ 2Pusat Teknologi Terapan Kesehatan dan Epidemiologi Klinik, Badan Litbangkes, Jakarta \\ ${ }^{3}$ Pusat Teknologi Intervensi Kesehatan Masyarakat, Badan Litbangkes, Jakarta \\ idrus2404@gmail.com
}

\begin{abstract}
ABSTRAK
Anemia, terutama anemia defisiensi besi, masih merupakan masalah kesehatan masyarakat di Indonesia. Prevalensi anemia masih tinggi pada kelompok risiko tinggi yaitu ibu hamil, menyusui, balita, anak usia sekolah dan WUS. Selain kekurangan zat besi dalam konsumsi makanan dan penyakit infeksi, berbagai faktor mempunyai kontribusi relatif terhadap anemia. Tulisan ini bertujuan untuk mengetahui kontribusi relatif status retinol terhadap anemia pada anak usia sekolah. Penelitian dilakukan di Tasikmalaya dan Ciamis pada 173 anak umur 5-9 tahun dari keluarga miskin. Hasil penelitian menunjukkan prevalensi anemia 14,5 persen, prevalensi kurang vitamin A (KVA) 10,9 persen. Konsumsi energi, protein, zat besi, vitamin C, vitamin $B_{12}$, folat, dan seng masih di bawah AKG (2004). Setelah dikontrol dengan asupan energi, protein, dan vitamin $B_{12}$ anak yang menderita KVA memiliki odds ratio 3,33 kali untuk menjadi anemia ( $p=0.063,95 \%, \mathrm{Cl}$ 0,93-11.84) dibandingkan anak yang tidak KVA.
\end{abstract}

Kata kunci: anemia, defisiensi vitamin A, anak usia sekolah

\section{THE ASSOCIATION BETWEEN VITAMIN A DEFICIENCY AND ANEMIA AMONG SCHOOLAGE CHILDREN}

\section{ABSTRACT}

Anemia, particularly iron deficiency anemia, is one of the major public health nutrition problem in Indonesia. The prevalence is still high among high risk groups namely pregnant and lactating mother, children underfives, schoolage children, and woman of reproductive age. The major causes of anemia are low intake and low bioavailability of iron. However, vitamin A status and other nutrient intakes have been reported to contribute to anemia. The study determines relative contribution of vitamin A status (serum retinol) to anemia. Samples are 173 children age 6-9 year old of poor households in Tasikmalaya and Ciamis districts. The study found the prevalence of anemia in children 6-9 year old is 14.5 percent and vitamin A deficiency (VAD) is 10.9 percent. Odds ratio of children suffering VAD on anemia is 3.33 $\left(p=0.063,95 \% \mathrm{Cl} 0.93-11.84\right.$ ) after controlling for intakes of energy, protein, and vitamin $B_{12}$.

Keywords: anemia, vitamin A deficiency, schoolage children

\section{PENDAHULUAN}

A nemia, terutama anemia defisiensi besi, diakui sebagai gangguan gizi yang paling umum di dunia, yang mempengaruhi lebih dari dua miliar orang di negara maju dan negara-negara berkembang. Demikian juga kekurangan vitamin A juga masih merupakan masalah kesehatan masyarakat yang utama di dunia 1 Kelompok yang rentan menderita anemia ini adalah ibu hamil, ibu menyusui, balita, anak usia sekolah dan wanita usia subur.

Menurut Organisasi Kesehatan Dunia, WHO, diperkirakan prevalensi keseluruhan anemia pada anak prasekolah di negara berkembang adalah 42 persen. ${ }^{2}$ Sementara untuk data anemia pada anak usia sekolah di Indonesia masih terbatas. Data Survei Kesehatan Rumah Tangga (SKRT) tahun 2004 menunjukkan jumlah penderita anemia pada anak usia 5-11 tahun mencapai 24 persen. ${ }^{3}$

Kekurangan zat besi, kekurangan vitamin A, dan peradangan dapat menyebabkan anemia pada anak-anak, tapi kontribusi relatif dari berbagai faktor belum diketahui dengan baik. Kekurangan zat besi adalah penyebab utama anemia pada anak-anak prasekolah di seluruh dunia, ${ }^{4}$ dan anemia defisiensi besi telah dikaitkan dengan perkembangan psikomotor yang tertunda dan gangguan pertumbuhan, serta kelelahan.5,6,7 
Sedangkan kekurangan vitamin A diketahui dapat memicu terjadinya anemia. Beberapa penelitian telah menunjukkan bahwa kekurangan vitamin $\mathrm{A}$ dapat menyebabkan gangguan pada metabolism zat besi.8,9,10 Kekurangan vitamin A dapat menyebabkan anemia melalui efek pada metabolisme besi, hematopoiesis, dan peningkatan kerentanan terhadap infeksi. ${ }^{11}$

Studi lain menunjukkan bahwa asupan besi yang lebih tinggi dikaitkan dengan penurunan prevalensi anemia. ${ }^{12}$ Namun, hanya sepertiga dari kejadian anemia pada populasi dapat dikaitkan dengan defisiensi besi dan ada kemungkinan bahwa faktor-faktor penting lainnya mempengaruhi prevalensi anemia di wilayah tersebut. ${ }^{13}$

Beberapa penelitian gizi dari seluruh dunia menunjukkan hubungan yang erat antara kekurangan vitamin $\mathrm{A}$ dan anemia. ${ }^{14,15}$ Ada bukti yang jelas dari hubungan antara serum retinol dan indikator zat besi ${ }^{16,17,18}$, dan kekurangan vitamin A dianggap sebagai salah satu penyebab anemia. ${ }^{11}$

Berdasarkan kajian tersebut, penelitian ini bertujuan untuk mengetahui lebih lanjut tentang hubungan kekurangan vitamin $A$ dengan anemia pada anak usia sekolah.

\section{METODE PENELITIAN}

Penelitian ini merupakan bagian dari penelitian awal Riset Khusus "Evaluasi Dampak Fortifikasi Minyak Goreng Dengan Vitamin A", Badan Penelitian dan Pengembangan Kesehatan, Kementerian Kesehatan RI tahun 2011. Desain penelitian adalah cross-sectional. Penelitian dilaksanakan pada bulan Juni-Juli 2011 di dua kabupaten, yaitu Kabupaten Tasikmalaya dan Ciamis di 8 kecamatan periurban. Di tiap-tiap kecamatan dipilih 3 desa peri-urban, sehingga keseluruhan terdapat 24 desa. Hanya anak kelompok umur 6-9 tahun yang dianalisis dalam tulisan ini, sedangkan kelompok lainnya tidak dianalisis.

\section{Unit Sampel dan besar sampel}

Unit pengambilan sampel adalah rumahtangga miskin yang mempunyai anak sekolah usia 5-9 tahun di 24 desa sekitar kota yang terpilih (clusters). Definisi rumahtangga miskin berdasarkan keberadaan kartu keluarga miskin baik dari kriteria pemerintah pusat maupun daerah setempat. Hanya rumahtangga yang memiliki kartu tersebut yang dipilih untuk menjadi sampel. Kriteria inklusi meliputi: anak usia sekolah berusia 5-9 tahun, tidak ada indikasi berlawanan dengan sampling darahnya (misalnya, hemofilia), tidak mengidap penyakit serius (kronis atau akut), dan tidak mengidap anemia yang serius $(<7 \mathrm{~g} / \mathrm{dl})$.

\section{Pengumpulan data}

Pengumpulan data menggunakan kuesioner yang sudah dilakukan pengujian lapangan dan terstruktur yang dilakukan oleh enumerator/pewawancara yang sudah dilatih terlebih dahulu.Pendidikan minimal enumerator adalah Diploma III kesehatan yang bekerja di Puskesmas maupun Dinas Kesehatan Kabupaten Tasikmalaya dan Kabupaten Ciamis. Pada saat pengumpulan data direkrut juga koordinator lapangan di kabupaten Tasikmalaya dan Ciamis yang bertugas mengawasi secara langsung pada proses pengumpulan data.

\section{Pengambilan darah}

Darah diambil dari vena mediana cubiti. Darah vena dibagi menjadi 2 (dua) bagian, yaitu darah EDTA dan darah tanpa anticoagulan (plain). Darah EDTA digunakan untuk pengukuran hemoglobin dengan menggunakan hemocue dan dibaca langsung di tempat. Darah tanpa anticoagulan dimasukkan dalam vacutainer untuk dilakukan centrifuge. Darah tanpa anticoagulan ini setelah di-centrifuge dipisahkan bagian jernih (serum) dari endapan sel-sel darah. Serum dibagi menjadi 2 (dua) vial ukuran $1,5 \mathrm{ml}$, masing masing vial berisi $0,5 \mathrm{ml}$. Kemudian vial-vial tersebut ditempatkan dalam rak tabung dan selanjutnya disimpan dalam cool box dengan suhu $-4^{\circ} \mathrm{C}$. Bila subjek menderita anemia berat, subyek dirujuk ke Puskesmas terdekat.

\section{Analisis sampel}

Data biokimia meliputi kadar hemoglobin dan kadar vitamin A. Kurang vitamin A apabila kadar vitamin A kurang dari $20 \mathrm{ug} / \mathrm{dl}$. Anemia adalah keadaan dimana seseorang mempunyai kadar hemoglobin di bawah nilai normal berdasarkan jenis kelompok umur dan jenis kelamin. Untuk subjek usia 2-11 tahun dikategorikan anemia bila kadar $\mathrm{Hb}$ kurang dari $11,5 \mathrm{~g} / \mathrm{dl}$. 
Hemoglobin diukur menggunakan alat ukur HemocueTM portabel dan hemocuvettes (Hemocue, Aangelsborg, Swedia). Pengukuran dilakukan langsung di fasilitas kesehatan desa, dan hasilnya dicatat pada formulir individu dan dikomunikasikan kepada subyek yang bersangkutan. Untuk pemeriksaan serum retinol, serum yang disimpan dalam cool box , segera dikirim ke laboratorium pusat PT P di Jakarta untuk dianalisa kadar retinol dengan menggunakan HPLC.

\section{Pemeriksaan Hemoglobin Metode Cyanmeth dengan Hemocue:}

Siapkan alat hemocue dengan membaca blangko terlebih dahulu, kemudian membaca standar sebelum digunakan untuk pembacaan sampel guna melihat apakah alat stabil. Letakkan ujung cuvette hemocue di permukaan sampel darah sampai cuvette terisi oleh darah. Kemudian dibaca dengan alat hemocue, selanjutnya ditunggu sekitar 1 menit, maka akan keluar kadar $\mathrm{Hb}$ di layar monitor hemocue

\section{Data konsumsi makanan}

Pengumpulan data konsumsi makanan dilakukan dengan metode food recall $2 \times 24$ jam, dengan tidak diambil secara berurutan untuk mengontrol terhadap variasi dan jumlah makanan yang dikonsumsi oleh sampel. Wawancara recall konsumsi dilakukan terhadap anak usia sekolah 5-9 tahun di rumahtangga dengan pendampingan orangtua anak. Beberapa makanan jadi yang banyak dikonsumsi anak di tiap desa terpilih yang belum diketahui bahan dan beratnya dibeli dan ditimbang dengan food scale untuk memperkiraan berat bahan makanannya lebih tepat.

\section{Manajemen Data}

Manajemen data termasuk memeriksa kelengkapan data, entri data, verifikasi data, dan cleaning data. Untuk memastikan kualitas data yang dikumpulkan, tiga prosedur pengendalian kualitas data diterapkan dalam studi. Ketiga prosedur kualitas data adalah: pretest-kuesioner, uji variasi antar pewawancara, dan supervisi. Pretest kuesioner dilakukan dua kali di Bogor dan di daerah penelitian saat pelatihan.

Untuk mengontrol variasi antar-enumerator, pelatihan enumerator dilakukan sebelum pengumpulan data. Tujuan utama dari pelatihan ini adalah untuk membakukan pemahaman enumerator tentang studi dan kewajiban mereka, dan memastikan bahwa enumerator memiliki kemampuan yang sebanding dalam pengumpulan data dan manajemen termasuk mengidentifikasi dan memecahkan masalah yang mungkin muncul selama pelaksanaan penelitian. Enumerator adalah petugas tenaga pelaksana gizi (TPG) Puskesmas degan latar belakang pendidikan gizi.

Panduan untuk pengumpulan data terdiri dari petunjuk wawancara dan pedoman pengisian kuesioner. Pengawasan dilakukan oleh tim peneliti dan koordinator lapangan. Tujuan pengawasan meliputi: 1) pengendalian operasional oleh tim peneliti untuk memecahkan semua masalah yang muncul selama pengumpulan data dan 2) pengawasan teknis oleh koordinator lapangan/ supervisor untuk mengendalikan kelengkapan dan validitas instrumen untuk wawancara.

Sumber utama untuk kesalahan selama pengumpulan sampel adalah ketidaklengkapan data, salah pelabelan dan penyimpanan data kurang baik. Data tidak lengkap dipantau dengan menggunakan lembar ringkasan desa dan lembar ringkasan sampel. Penomoran identitas sampel dilakukan untuk semua kuesioner individu, rumahtangga, antropometri, spesimen darah, konsumsi makanan.

Pemeriksaan terhadap kelengkapan formulir pengumpulan data/ kuesioner dilakukan langsung di lapangan untuk memastikan apakah nomor identifikasi telah diberikan untuk masing-masing formulir dan juga untuk memeriksa data yang tidak lengkap. Koordinator lapangan bertanggung jawab untuk tugas ini. Kontrol data juga dilakukan untuk konsistensi semua variabel yang saling terkait. Bila kuesioner yang tidak lengkap, koordinator lapangan kembali ke rumahtangga masingmasing dan menyelesaikan kelengkapan kuesioner.

Pengendalian mutu di tingkat analisa laboratorium diterapkan untuk semua indikator pada dua tingkatan yaitu: pra-analisis yang bertujuan untuk memastikan bahwa peralatan yang dipilih dan cara kerja/prosedur kerja sudah tepat dan memadai, dan selama analisis yang bertujuan untuk memastikan bahwa proses berlangsung dengan tepat. Untuk 
hemocue, alat dikontrol setiap hari dan catatan kontrol tersebut dicatat dan disimpan.

\section{Pengolahan Data}

Data yang dikumpulkan diberi kode berdasarkan codebook yang sudah disusun. Semua data yang terkumpul kemudian dimasukkan ke dalam komputer dengan menggunakan program data entry (Foxpro). Cleaning data dilakukan untuk memeriksa kelengkapan dan konsistensi informasi yang telah dimasukkan ke dalam komputer. Dalam kasus data tidak lengkap atau kurang jelas, koordinator lapangan melengkapi dengan kunjungan ke subyek.

\begin{abstract}
Analisis Data
Analisis univariat dilakukan untuk mengetahui sebaran masing-masing variabel, dan untuk mengetahui distribusi variabel menurut kategori anemia pada anak usia sekolah digunakan analisis bivariat. Selanjutnya analisis multivariate logistic regression digunakan untuk mengetahui hubungan antara kekurangan vitamin $\mathrm{A}$ dengan anemia pada anak usia sekolah.
\end{abstract}

\section{Etik Penelitian}

Penelitian ini telah mendapatkan persetujuan etik (ethical clearance) dari Komisi Etik, Badan Penelitian dan Pengembangan Kesehatan, Kementerian Kesehatan RI.

Tabel 1

Karakteristik Data Baseline

\begin{tabular}{|c|c|c|c|}
\hline Karakteristik Sampel & Mean & Median & Standar Error \\
\hline Hemoglobin (g/dl) & 12,57 & 12,6 & 0,085 \\
\hline Serum retinol $(\mu \mathrm{g} / \mathrm{dl})$ & 34,83 & 33,7 & 1,004 \\
\hline Umur (bulan) & 88,7 & 88,0 & 1,13 \\
\hline \multicolumn{4}{|l|}{ Asupan Energi (kkal) } \\
\hline - 5-6 tahun $(\mathrm{AKG}=1550)$ & 1120,44 & 1022,5 & 114,69 \\
\hline - 7-9 tahun $(\mathrm{AKG}=1800)$ & 1155,74 & 1055 & 39,91 \\
\hline \multicolumn{4}{|l|}{ Asupan Protein $(\mathrm{g})$} \\
\hline - 5-6 tahun (AKG=39) & 35,33 & 31,39 & 4,38 \\
\hline - 7-9 tahun (AKG=45) & 33,24 & 31,86 & 1,20 \\
\hline \multicolumn{4}{|l|}{ Asupan Besi (mg) } \\
\hline - 5-6 tahun (AKG=9) & 5,39 & 4,25 & 0,81 \\
\hline - 7-9 tahun $(\mathrm{AKG}=10)$ & 6,22 & 4,73 & 0,57 \\
\hline \multicolumn{4}{|l|}{ Asupan Vitamin C (mg) } \\
\hline - 5-6 tahun $(\mathrm{AKG}=45)$ & 17,36 & 12,0 & 2,44 \\
\hline - 7-9 tahun (AKG=45) & 14,98 & 9,75 & 1,68 \\
\hline \multicolumn{4}{|l|}{ Asupan Folat $(\mu \mathrm{g})$} \\
\hline - 5-6 tahun $(\mathrm{AKG}=200)$ & 108,86 & 73,5 & 22,61 \\
\hline - 7-9 tahun $(A K G=200)$ & 102,97 & 77,5 & 6,42 \\
\hline \multicolumn{4}{|l|}{ Asupan Vitamin $B_{12}(\mu \mathrm{g})$} \\
\hline - 5-6 tahun $(A K G=5)$ & 1,59 & 1,44 & 0,21 \\
\hline - 7-9 tahun $(\mathrm{AKG}=1,5)$ & 1,43 & 1,2 & 0,11 \\
\hline \multicolumn{4}{|l|}{ Asupan Seng (mg) } \\
\hline - 5-6 tahun $(\mathrm{AKG}=9,7)$ & 4,18 & 3,42 & 0,59 \\
\hline - 7-9 tahun $(\mathrm{AKG}=11,2)$ & 3,87 & 3,7 & 0,14 \\
\hline
\end{tabular}

\section{HASIL}

\section{Karakteristik sampel}

Jumlah sampel dalam penelitian ini adalah 173 anak, yang terdiri dari laki-laki 78 anak dan perempuan 95 anak. Rata-rata hemoglobin didapatkan 12,57 $\pm 1,087 \mathrm{~g} / \mathrm{dl}$, dan rata-rata serum retinol $34,83 \pm 12,82 \mu \mathrm{g} / \mathrm{dl}$. Rata-rata umur anak $88,7 \pm 13,4$ bulan. Sedangkan untuk asupan energi, protein, besi, folat, vitamin $\mathrm{B}_{12}$, 
dan seng dihitung menurut kelompok umur 5-6 tahun dan kelompok umur 7-9 tahun sesuai dengan Angka Kecukupan Gizi (AKG, 2004). ${ }^{19}$ Hasil penelitian menunjukkan bahwa rata-rata asupan energi, protein, besi, vitamin $C$, folat, vitamin $B_{12}$, dan seng masih di bawah AKG (2004), baik pada kelompok umur 5-6 tahun maupun kelompok umur 7-9 tahun. Secara lengkap gambaran karakteristik sampel dapat dilihat pada Tabel 1.

\section{Prevalensi anemia dan kekurangan vitamin A}

Pada penelitian ini didapatkan prevalensi anemia pada anak usia sekolah sebesar 14,5 persen $(n=25), \quad$ sedangkan prevalensi kekurangan vitamin $\mathrm{A}(<20 \mu \mathrm{g} / \mathrm{dl})$ sebesar 10,9 persen $(n=19)$.

Tabel 2

Distribusi Anemia pada Anak Usia Sekolah menurut Status Vitamin A

\begin{tabular}{lcccccc}
\hline \multirow{2}{*}{ Status vitamin A } & \multicolumn{2}{c}{ Anemia } & & OR & $95 \% \mathrm{Cl}$ \\
\cline { 2 - 4 } & $\begin{array}{c}\text { Ya } \\
\%\end{array}$ & $\begin{array}{c}\text { Tidak } \\
\%\end{array}$ & p-value & & & \\
\hline Kurang $(<20)$ & 27,8 & 72,2 & 0,087 & 2,714 & $0,86-8,51$ \\
Cukup $(\geq 20)$ & 12,4 & 87,6 & & & \\
\hline
\end{tabular}

Dari hasil analisis bivariat menunjukkan bahwa persentase anak usia sekolah yang kekurangan vitamin A dan mengalami anemia sebesar 27,8 persen. Sedangkan persentase anak usia sekolah yang cukup vitamin A mengalami anemia sebesar 12,4 persen (Tabel 2).Menurut jenis kelamin, diperoleh persentase anemia pada laki-laki $(16,7 \%)$ lebih tinggi dibandingkan pada perempuan $(12,6 \%)$. Selanjutnya menurut umur diketahui bahwa persentase anemia lebih tinggi pada kelompok umur 5-6 tahun $(15,2 \%)$ tahun dibandingkan umur 7-9 tahun $(14,0 \%)$ (Tabel 3).

Tabel 3

Distribusi Anemia pada Anak Usia Sekolah menurut Karakteristik (Jenis Kelamin dan Umur)

\begin{tabular}{ccccccc}
\hline & \multicolumn{3}{c}{ Anemia } & & & \\
\cline { 2 - 3 } Karakteristik & $\begin{array}{c}\text { Ya } \\
\%\end{array}$ & $\begin{array}{c}\text { Tidak } \\
\%\end{array}$ & p-value & OR & $95 \% \mathrm{Cl}$ \\
\hline $\begin{array}{c}\text { Jenis Kelamin } \\
\text { Laki-laki }\end{array}$ & 16,7 & 83,3 & 0,454 & 0,723 & $0,30-1,69$ \\
$\quad \begin{array}{c}\text { Perempuan } \\
\text { Umur (tahun) }\end{array}$ & 12,6 & 87,4 & & & \\
$5-6$ & 15,2 & 84,8 & 0,837 & 0,913 & $0,38-2,17$ \\
$7-9$ & 14,0 & 86,0 & & & \\
\hline
\end{tabular}

Persentase anemia pada anak usia sekolah menurut asupan energi, protein, besi, vitamin $C$, folat, vitamin $B_{12}$, dan seng dapat dilihat pada Tabel 4. Persentase anemia anak usia sekolah dengan asupan energi $<80 \%$ AKG (14\%) lebih tinggi dibandingkan persentase anemia anak usia sekolah dengan asupan energi $\geq 80 \%$ AKG $(8,5 \%)$. Persentase anemia anak usia sekolah dengan asupan protein $<70 \%$ AKG $(16,3 \%)$ lebih tinggi dibandingkan persentase anemia anak usia sekolah dengan asupan protein $\geq 70 \%$ AKG $(4,2 \%)$. Demikian juga pada persentase anemia anak usia sekolah dengan asupan besi, vitamin $C$, folat, vitamin $B_{12}$, dan seng yang kurang $(<100 \% A K G)$ lebih tinggi dibandingkan persentase anemia anak usia sekolah dengan asupan besi, folat, vitamin $B_{12}$, dan seng yang cukup ( $\geq 100 \% A K G)$. 
Tabel 4

Distribusi Anemia pada Anak Usia Sekolah menurut Asupan Zat Gizi

\begin{tabular}{|c|c|c|c|c|c|}
\hline \multirow[b]{2}{*}{ Asupan Zat Gizi } & \multicolumn{2}{|c|}{ Anemia } & \multirow[b]{2}{*}{$p$-value } & \multirow[b]{2}{*}{ OR } & \multirow[b]{2}{*}{$95 \% \mathrm{Cl}$} \\
\hline & $\begin{array}{l}\mathrm{Ya} \\
\%\end{array}$ & $\begin{array}{c}\text { Tidak } \\
\%\end{array}$ & & & \\
\hline \multicolumn{6}{|l|}{ Asupan Energi } \\
\hline$<80 \%$ AKG & 14,0 & 86,0 & 0,354 & 1,747 & $0,53-5,68$ \\
\hline$\geq 80 \%$ AKG & 8,5 & 91,5 & & & \\
\hline \multicolumn{6}{|l|}{ Asupan Protein } \\
\hline$<70 \%$ AKG & 16,3 & 83,7 & 0,053 & 4,481 & $0,98-20,48$ \\
\hline$\geq 70 \%$ AKG & 4,2 & 95,8 & & & \\
\hline \multicolumn{6}{|l|}{ Asupan Besi } \\
\hline$<100 \%$ AKG & 13,0 & 87,0 & 0,413 & 2,393 & $0,29-19,29$ \\
\hline$\geq 100 \%$ AKG & 5,9 & 94,1 & & & \\
\hline \multicolumn{6}{|l|}{ Asupan Vitamin C } \\
\hline$<100 \%$ AKG & 11,5 & 88,5 & 0,437 & 0,522 & $0,10-2,67$ \\
\hline$\geq 100 \%$ AKG & 20,0 & 80,0 & & & \\
\hline \multicolumn{6}{|l|}{ Asupan Folat } \\
\hline$<100 \%$ AKG & 12,8 & 87,2 & 0,500 & 2,055 & $0,25-16,70$ \\
\hline$\geq 100 \%$ AKG & 6,7 & 93,3 & & & \\
\hline \multicolumn{6}{|l|}{ Asupan Vitamin $B_{12}$} \\
\hline$<100 \%$ AKG & 11,7 & 88,3 & 0,766 & 0,844 & $0,27-2,58$ \\
\hline$\geq 100 \%$ AKG & 13,5 & 86,5 & & & \\
\hline \multicolumn{6}{|l|}{ Asupan Seng } \\
\hline$<100 \%$ AKG & 11,6 & 88,4 & 0,158 & 0,131 & $0,01-2,20$ \\
\hline$\geq 100 \%$ AKG & 50,0 & 50,0 & & & \\
\hline
\end{tabular}

Persentase anemia pada anak usia sekolah menurut asupan energi, protein, besi, vitamin $C$, folat, vitamin $B_{12}$, dan seng dapat dilihat pada Tabel 4. Persentase anemia anak usia sekolah dengan asupan energi $<80 \%$ AKG (14\%) lebih tinggi dibandingkan persentase anemia anak usia sekolah dengan asupan energi $\geq 80 \%$ AKG $(8,5 \%)$. Persentase anemia anak usia sekolah dengan asupan protein $<70 \%$ AKG $(16,3 \%)$ lebih tinggi dibandingkan persentase anemia anak usia sekolah dengan asupan protein $\geq 70 \%$ AKG (4,2\%). Demikian juga pada persentase anemia anak usia sekolah dengan asupan besi, vitamin $C$, folat, vitamin $B_{12}$, dan seng yang kurang (<100\%AKG) lebih tinggi dibandingkan persentase anemia anak usia sekolah dengan asupan besi, folat, vitamin $B_{12}$, dan seng yang cukup ( $\geq 100 \% A K G)$.

Dari hasil analisis bivariate (Tabel 2, Tabel 3, Tabel 4) dilanjutkan dengan langkah pemodelan yang diawali dengan mengikutsertakan semua potential confounder dan effect modifier dan selanjutnya dilakukan eliminasi effect modifier.Tahap pertama mengevaluasi variabel kovariat yang masuk dalam model, yaitu dengan melihat hasil $p$ value dari masing-masing variabel terkait dengan status anemia pada anak usia sekolah. Semua variabel kovariat yang memenuhi persyaratan dalam analisis multivariate ( $p$ value $<0,25$ ) atau secara substansi terkait dengan status anemia pada anak usia sekolah dimasukkan dalam pemodelan.

Selanjutnya dari hasil analisis multivariate logistic regression hubungan kekurangan vitamin A dengan anemia pada anak usia sekolah menunjukkan bahwa anak usia sekolah yang kekurangan vitamin $\mathrm{A}$ memiliki odds ratio 3,33 kali (Cl 95\%: 0,93-1,84) untuk berisiko anemia dibandingkan dengan anak usia sekolah yang cukup vitamin $\mathrm{A}$ setelah dikontrol dengan variabel asupan energi, asupan protein, dan asupan vitamin $\mathrm{B}_{12}$ (Tabel 5). 
Tabel 5

Nilai Koefisien Beta, Standar error, Nilai $p$, dan $\operatorname{Exp}(B)$ Model Akhir Hubungan Kekurangan Vitamin A dengan Anemia pada Anak Usia Sekolah

\begin{tabular}{lrrrrc}
\hline Variabel & $\mathrm{B}$ & Standard Error & $\mathrm{p}$ & Exp(B) & Cl: 95\% \\
\hline Kurang Vitamin A & 1.203 & 0.647 & 0.063 & 3.33 & $0,93-11,84$ \\
Asupan Energi & -0.967 & 0.838 & 0.248 & 0.37 & $0,07-1,96$ \\
Asupan Protein & 2.304 & 1.025 & 0.024 & 10.01 & $1,34-74,69$ \\
Asupan Vitamin $\mathrm{B}_{12}$ & -0.745 & 0.633 & 0.239 & 0.47 & $0,13-1,64$ \\
Konstanta & -2.751 & 0.773 & 0.000 & 0.06 & \\
\hline
\end{tabular}

\section{BAHASAN}

Hasil penelitian menunjukkan bahwa prevalensi anemia pada anak sekolah sebesar 14,5 persen. Prevalensi tersebut lebih rendah bila dibandingkan dengan prevalensi yang ditemukan pada penelitian tahun $2005 \mathrm{di}$ Samosir pada 50 anak SD kelas 4-6 sebesar 70,0 persen ${ }^{20}$ dengan metode pemeriksaan Sahli, di pesisir dan kota Makassar pada 141 anak 6-12 tahun sebesar 37,6 persen, ${ }^{21}$ tetapi mendekati prevalensi dengan studi lain di Makassar pada 96 anak SD dengan prevalensi 20,6 persen. ${ }^{22}$

Hasil penelitian juga menunjukkan prevalensi kurang vitamin A sebesar 10,9 persen. Penelitian kurang vitamin A lebih banyak dilakukan pada anak balita dan tidak ada penelitian dilakukan ada anak usia sekolah. Pada anak balita prevalensi tahun 1992 dengan tanda bercak Bitot telah menurun menjadi 0,33 persen walaupun masih sekitar 50 persen mempunyai kadar serum retinol di bawah 20 $\mu \mathrm{g} / \mathrm{dl} .{ }^{23}$

Hasil penelitian menunjukkan bahwa anak usia sekolah umur 5-9 tahun yang kekurangan vitamin $A$ cenderung berisiko mengalami anemia sebesar 3,33 kali $(p=0.063)$ dibandingkan anak usia sekolah umur 5-9 tahun yang cukup vitamin A setelah dikontrol variabel asupan energi, asupan protein, dan asupan vitamin $B_{12}$. Walaupun tidak signifikan, kecenderungan adanya risiko yang lebih tinggi jika anak kurang vitamin A juga menderita anemia jelas terlihat lebih dari 3 kali lebih besar.

Dalam penelitian sebelumnya dengan metode uji klinis terkontrol diketahui bahwa suplementasi vitamin $\mathrm{A}$ atau fortifikasi makanan dapat meningkatkan konsentrasi hemoglobin pada anak-anak prasekolah di Indonesia, ${ }^{24}$ Guatemala ${ }^{8}$, dan Tanzania ${ }^{25}$, atau meningkatkan indikator status zat besi pada anak-anak prasekolah di Indonesia ${ }^{26}$ dan di Thailand. ${ }^{27}$

Selanjutnya diketahui bahwa suplemen vitamin A gabungan dengan suplementasi zat besi telah terbukti memiliki pengaruh lebih besar pada peningkatan konsentrasi hemoglobin daripada vitamin A saja. ${ }^{25,9}$ Menurut Semba dan Bloem (2002) bahwa strategi yang ditujukan pada kedua masalah yaitu kekurangan vitamin A dan kekurangan zat besi dapat lebih efektif dalam mengurangi kejadian anemia. ${ }^{11}$

Sebagaimana diketahui bahwa efisiensi penggunaan zat besi makanan oleh tubuh dipengaruhi faktor makanan dan individu. ${ }^{28,29}$ Faktor makanan meliputi: (1) bentuk fisiko-kimia zat besi, dan (2) faktor makanan yang mempengaruhi jumlah zat besi luminal yang tersedia untuk penyerapan usus. Sementara faktor individu mencakup pengaturan homeostatis mukosa untuk mengambil dan mentransfer zat besi ke tubuh, baik yang beradaptasi dengan kebutuhan tubuh akan zat besi maupun yang beradaptasi dengan inflamasi. ${ }^{28}$ Hasil penelitian ini menunjukkan sebagian besar zat gizi, kecuali asupan protein, tidak menunjukkan peran yang signifikan terhadap status anemia. Kurang berperannya asupan makanan dalam penelitian ini dimungkinkan karena metode pengukuran yang digunakan dan desain penelitian. Metode food recall diketahui memiliki keterbatasan dalam pelaksanaan di lapangan, baik dalam jumlah maupun frekuensi makanan yang dikonsumsi oleh responden. Sedangkan penelitian lain di Makassar menunjukkan hubungan yang signifikan antara kadar hemoglobin dengan 
asupan zat besi heme, frekuensi konsumsi makanan pelancar absorpsi zat besi. ${ }^{21}$ Pentingnya pengetahuan dan sikap ibu, perhatian dan dukungan ibu terhadap kesehatan anak terutama terhadap anemia juga mempunyai peran signifikan terhadap kejadian anemia. ${ }^{22}$ Penelitian tersebut juga menunjukkan status sosial ekonomi rumahtangga dan pendidikan berperan nyata dalam peningkatan nilai hemoglobin anak.

Organisasi Kesehatan Dunia, WHO, menyebutkan bahwa anemia, terutama anemia defisiensi besi dan masalah kurang gizi lainnya, merupakan konsekuensi dari kemiskinan. Akan tetapi intervensi tetap perlu dilakukan untuk mencegah anemia mengingat konsekuensi terhadap peningkatan morbiditas dan resistensi terhadap infeksi, konsekuensi terhadap perkembangan kognisi anak, hambatan pertumbuhan anak, maupun konsekuensi anemia pada usia selanjutnya. Penurunan angka kemiskinan, penganekaragaman makanan yang bergizi, peningkatan pelayanan kesehatan dan sanitasi lingkungan, dan peningkatan perawatan anak dan pemberian makanan. ${ }^{30}$

Pada anak usia sekolah tidak ada program gizi yang khusus seperti pada anak balita. Oleh karena itu di bidang gizi perlu berbagai strategi program gizi yang mendukung adanya perbaikan konsumsi makanan yang masih kurang bervariasi seperti ditemukan dalam analisis hasil Susenas yang menunjukkan bahwa akses terhadap bahan makanan tinggi mikronutrien, perbaikan pola pemberian makanan kepada anak, peningkatan pengetahuan keluarga tentang gizi. ${ }^{23}$ Selain itu fortifikasi makanan merupakan salah satu upaya peningkatan konsumsi zat gizi mikro. Fortifikasi wajib pada terigu yang sudah dilakukan di Indonesia perlu terus dengan zat besi, zinc, folat, vitamin $B_{12}$, vitamin $B_{2}$ perlu terus dipertahankan. ${ }^{31}$

\section{SIMPULAN DAN SARAN}

\section{Simpulan}

Adanya kecenderungan anak usia sekolah umur 5-9 tahun yang kekurangan vitamin $A$ berisiko mengalami anemia sebesar 3,33 kali $(p=0.063)$ dibandingkan anak usia sekolah umur 5-9 tahun yang cukup vitamin A setelah dikontrol variabel asupan energi, asupan protein, dan asupan vitamin $B_{12}$.

\section{Saran}

Perlu adanya program pilihan untuk mengatasi kekurangan vitamin $A$ maupun anemia pada anak sekolah umur 5-9 tahun. Kegiatan penyuluhan makanan sehat dan bergizi di sekolah, ataupun menyediakan fasilitas warung sehat di sekolah diharapkan dapat menjadi program alternatif. Di samping perlu dipikirkan untuk membuat produk makanan yang difortikasi zat besi ataupun vitamin $A$ untuk mencukupi kebutuhan micronutrient khususnya pada anak sekolah umur 5-9 tahun.

\section{UCAPAN TERIMA KASIH}

Ucapan terima kasih disampaikan kepada Kepala Badan Penelitian dan Pengembangan Kesehatan Kementerian Kesehatan RI, Robert $L$ Tielden selaku konsultan penelitian, Kepala Dinas Kesehatan Provinsi Jawa Barat, Kepala Dinas Kabupaten Tasikmalaya dan Kabupaten Ciamis, serta jajarannya mulai dari Sub-Dinas, Kepala Puskesmas, dokter Puskesmas, Tenaga Pelaksana Gizi Puskesmas, bidan desa yang telah membantu dalam kelancaran pelaksanaan penelitian ini. Ucapan terima kasih juga disampaikan kepada pihak PT Prodia yang melaksanakan pengumpulan data biokimia. Juga kepada para enumerator yang telah melakukan wawancara dan pengumpulan data dengan tekun.

\section{RUJUKAN}

1. World Health Organization. Nutrition for health and development. A Global agenda for combating malnutrition. WHO/NHD/2000.6. Geneva: WHO, 2000.

2. Administrative Committee on Coordination/Sub-Committee on Nutrition (ACC/SCN. Fourth Report on the World Nutrition Situation. Geneva: ACC/SCN, 2000

3. Badan Litbang Kesehatan. Survei Kesehatan Rumah Tangga 2004. Jakarta: Badan Litbang Kesehatan, 2004.

4. Allen L \& Casterline-Sabel J. Prevalence and causes of nutritional anemias. In 
Nutritional Anemias, ed. U Ramakrishnan. Boca Raton, FL: CRC Press, 2001.

5. Balarajan Y, Ramakrishnan U, Ozaltin E, Shankar AH, SubramanianSV. Anaemia in low-income and middle-income countries. Lancet. 2011; 378: 2123-35.

6. Stoltzfus RJ, Mullany L, Black RE. Iron deficiency anaemia. In: EzzatiM, Lopez AD, Rodgers A, Murray CJL, eds. Comparative Quantificationof Health Risks: Global and Regional Burden of Disease Attributable toSelected Major Risk Factors. Geneva: World Health Organization, 2004

7. Lozoff $B$ \& Wachs TD. Functional correlates of nutritional anemias in infancy and early childhood - child development and behavior. In Nutritional Anemias, ed. U Ramakrishnan. Boca Raton, FL: CRC Press, 2001.

8. Mejia LA, Chew F. Haematological effect of supplementing anaemic children with vitamin $\mathrm{A}$ alone and in combination with iron. Am J Clin Nutr. 1988; 48: 595-600.

9. Suharno D, West CE, Muhilal, Karyadi D, Hautvast JGAJ. Supplementation with vitamin $A$ and iron for nutritional anaemia in pregnant women in West Java, Indonesia. Lancet. 1993; 342: 1325-1328.

10. Ahmed F, Khan MR, Karim R, Taj S, Hyderi $T$, Faruque $M O$, et al. Serum retinol andbiochemical measures of iron status in adolescent schoolgirls in urban Bangladesh. Eur J Clin Nutr. 1996; 50:346351.

11. Semba RD \& Bloem MW. The anemia of vitamin A deficiency: epidemiology and pathogenesis. Eur. J. Clin. Nutr. 2002; 56: 271-281.

12. Hashizume M, Shimoda T, Sasaki S, Kunii O, Caypil W,Dauletbaev D, et al. Anaemia in relation to low bioavailabilityof dietary iron among school-aged children in the AralSea region, Kazakhstan. International Journal of FoodSciences and Nutrition 2004; 55(1): 37-43.

13. Hashizume M, Kunii O, Sasaki S, Shimoda T, Wakai S,Mazhitova Z, et al. Anemia and iron deficiency amongschoolchildren in the Aral Sea region, Kazakhstan. Journal ofTropical Pediatrics 2003; 49(3): 172-7.

14. Majia LA, Hodges RE, Arroyave G, Viteri F, Torun B.Vitamin A deficiency and anemia in Central Americanchildren. American
Journal of Clinical Nutrition 1977;30(7): 1175-84.

15. Bloem MW, Wedel M, Egger RJ, Speek AJ, Schrijver J,Saowakontha S, et al. Iron metabolism and vitamin Adeficiency in children in northeast Thailand. AmericanJournal of Clinical Nutrition 1989; 50(2): 332-8.

16. Mejia $L A$, Arroyave $G$. The effect of vitamin A fortification of sugar on iron metabolism in preschool children in Guatemala. The American Journal of Clinical Nutrition 1982; 36(1): 87-93.

17. Ahmed F, Khan MR, Karim R, Taj S, Hyderi $\mathrm{T}$, Faruque MO,et al. Serum retinol and biochemical measures of iron statusin adolescent schoolgirls in urban Bangladesh. EuropeanJournal of Clinical Nutrition 1996; 50(6): 346-51.

18. Ahmed F, Khan MR, Islam M, Kabir I, Fuchs GJ. Anaemia andiron deficiency among adolescent schoolgirls in periurbanBangladesh. European Journal of Clinical Nutrition 2000;54(9): 678-83.

19. Departemen Kesehatan. Keputusan Menteri Kesehatan Republik Indonesia nomor 913/Menkes/SK/VII/2002 tentang Angka Kecukupan Gizi yang Dianjurkan bagi bangsa Indonesia. Jakarta: Depkes, 2002.

20. Sinaga $\mathrm{E}$. Hubungan antara kadar $\mathrm{Hb}$ dengan prestasi belajar pada murid SD Negeri no. 173728 Lobutua Kecamatan Palipi Kabupaten Samosir Tahun 2005. Jurnal Mutiara Kesehatan Indonesia 2005; 1 (2): 15-21.

21. Nurnia, Hadju V, Citrakesumasari. Hubungan pola konsumsi dengan status hemoglobin anak sekolah dasar di wilayah pesisir dan kota Makassar. Makassar. Laporan Penelitian. Makasar: Unhas Bagian Gizi FKM, 2013.

22. Syafri M, Sirajuddin S, Tawali A. Hubungan faktor keluarga dan anak dengan kejadian anemia pada anak Sekolah Dasar Inpres Cilallang, Kota Makassar tahun 2013. Laporan Penelitian. Makasar: Unhas Bagian Gizi FKM, 2013.

23. Atmarita. Nutrition problems in Indonesia. Paper presented at Integrated International Seminar and Workshop on Lifestyle Related Disease, Jogyakarta, 19-20 March 2005. 
24. Muhilal, Permeisih D, Idjradinata YR, Muherdiyantiningsih \& Karyadi, D. Vitamin A-fortified monosodium glutamate and health, growth, and survival of children: a controlled field trial. Am. J. Clin. Nutr. 1998;48: 1271-1276.

25. Mwanri L, Worsley A, Ryan P \& Masika, J. Supplemental vitamin A improves anemia and growth in anemic school children in Tanzania. J. Nutr. 2000; 130: 2691-2696.

26. Semba, RD, Muhilal, West Jr, KP, Winget, M, Natadisastra, G, Scott, A, et al. Impact of vitamin $A$ supplementation on hematological indicators of iron metabolism and protein status in children. Nutr. Res. 1992;12: 469-478.

27. Bloem, MW, Wedel, M, van Agtmaal, EJ, Speek, AJ, Saowakontha, S \& Schreurs, WHP. Vitamin A intervention: short-term effects of a single, oral, massive dose on iron metabolism. Am. J. Clin. Nutr. 1990;51: 76-79.

28. Aggett, PJ. Iron. In: Erdman Jr JW, Macdonald IA, Zeisel SH, eds. Present Knowledge in Nutrition. 10th Edition. Ames: John Wiley \& Sons, 2012.

29. McDermid, JM and Lönnerdal, B. Iron. $\underline{\mathrm{Adv}}$ Nutr. 2012; 3: 532-3.

30. World Health Organization. Iron Deficiency Anemia: Assessment, Prevention, and Control: A Guide for Programme Managers. Geneve: WHO, 2001.

31. Departemen Perindustrian dan Perdagangan. Peraturan Menteri Perindustrian nomor 153/MPP/Kep/5/2001tanggal 2 Mei 2001, tentang Penerapan secara wajib SNI tepung terigu sebagai bahan makanan. Jakarta: Departemen Perindustrian, 2001. 